\title{
An Analysis of the Relationship between High School Students' Self-efficacy, Metacognitive Strategy Use and their Academic Motivation for Learn Biology
}

\author{
Solmaz Aydın \\ Correspondence: Solmaz Aydın, Department of Science Education, Kafkas University, Kars, Turkey. \\ Received: October 8, 2015 Accepted: October 9, 2015 Online Published: October 28, 2015 \\ doi:10.11114/jets.v4i2.1113 \\ URL: http://dx.doi.org/10.11114/jets.v4i2.1113
}

\begin{abstract}
This study aimed to analyze the relationship between high school students' self-efficacy perceptions regarding biology, the metacognitive strategies they use in this course and their academic motivation for learn biology. The sample of the study included 286 high school students enrolled in three high schools who attended a biology course in Kars, Turkey. Survey method was employed in the study. The author administered 'Self Efficacy for Learning and Performance' and 'Metacognitive Self-Regulation' subscales of Motivational Strategies for Learning Questionnaire (MSLQ) and Academic Motivation Scale for Learning Biology. According to the study results, the use of metacognitive strategies and self-efficacy made a positive and significant prediction of students' intrisic motivation to learn biology. Moreover, self-efficacy made a negative prediction of amotivation, and it did not predict extrinsic motivation. The use of metacognitive strategies did not predict amotivation, and it positively and significantly predicted extrinsic motivation. In addition, it was found that amotivation had a negative correlation with other variables.
\end{abstract}

Keywords: self-efficacy, metacognition, academic motivation, high school students, learn biology

\section{Introduction}

In the current educational system, some students are more willing to study and have a better understanding of the subjects while others have difficulty understanding and getting motivated for courses. Researchers take these issues into consideration and study the causes of this situation. Considering social cognitive perspective, it seems that self-regulation of learning and motivation should be highlighted. According to Zimmerman (2002), self-regulated individuals are aware of their own learning, determine personal goals, pick strategies to realize these goals, monitor their own behaviors and increase their own motivation. Self-regulated learners get motivated to learn and confident about their own abilities (Smith, 2001) and are identified by their use of self-regulated learning strategies (Zimmerman, 1989; 1990). Pintrich and De Groot (1990) suggest that students should also be motivated along with using self-regulated learning strategies to be successful. Based on these ideas, the author thought that students' self-efficacy and use of strategies could be relationship with motivation, and researched this relation using the structural equation model.

\subsection{Self-efficacy}

Self-efficacy is individuals' level of self-confidence in their abilities to manage certain tasks (Bandura, 1997), and it influences how people think, act and motivate themselves (Bandura, 1995). People who think that they have a high level of self-efficacy can work longer hours and withstand difficulties, while those who believe that their self-efficacy is low avoid completing tasks (Bandura, 1977). Bandura (1994) emphasized the importance of self-efficacy by suggesting that individuals' motivation and acts are dependent on what they believe rather than the actual situation. Pajares (1996) also said that self-efficacy has a big influence on motivation and behaviors.

Some people motivate themselves, guide their own acts and shape their beliefs according to what they can do. For this reason, self-efficacy belief plays a key role in the self-regulation of motivation (Bandura, 1993). When people think that they will not obtain the result they desire, they feel less willing to withstand difficulties. Thus, self-efficacy is the foundation of motivation and achievement (Pajares, 2002). Some researchers claim that self-efficacy has a predictive effect on students' achievement (Coutinho \& Neuman, 2008; Long, Monoi, Harper, Knoblauch \& Murphy, 2007; Pajares, 1996; Schunk, 1989). Moreover, Walker et al. (2006) determined that self-efficacy had a positive correlation 
with intrisic motivation, a negative correlation with amotivation and had no correlation with extrinsic motivation. Based on this information in the relevant literature, the author concluded that self-efficacy had a direct relationship with student motivation.

\subsection{The Use of Metacognitive Strategy}

Metacognition is a person's being informed and conscious about his or her own cognition (Flavell, 1979; Zimmerman, 2002). According to Flavell (1979), past studies have concluded that metacognition plays an important role in communication, reading comprehension, concentration, memory and problem solving. In these aspects, the knowledge of metacognition is important in education. Metacognition is classified into two types: 'knowledge of cognition' and 'regulation of cognition'. Knowledge of cognition is the things that people know about their own cognition. Regulation of cognition includes the metacognitive activities that help regulate cognition (Schraw \& Moshman, 1995).

Paris and Winograd (1990) said that teachers can increase students' metacognitive awareness by means of effective problem solving strategies and scientific discussions, and this will provide two benefits: 1) the teacher conveys the responsibility to students to watch their learning, and 2) students develop positive self-perception and motivation.

Landine and Stewart (1998) suggested that there was a positive correlation between intrinsic motivation, academic achievement and the use of metacognitive strategies. Similarly, Biggs (1985) said that intrinsic motivation is an important factor of metacognition and academic achievement. Biggs (1988) also said that metacognition had a major effect on increasing learning. Accordingly, Tas, Brown, Esen-Danaci, Lysaker and Brüne (2012) argued that metacognition is correlated with intrinsic motivation.

\subsection{Academic Motivation}

Motivation is to get into action to do something (Ryan \& Deci, 2000a). Deci and Ryan (1985) made a basic classification of motivation and suggested three categories: intrinsic motivation, extrinsic motivation and amotivation. Intrinsic motivation means that a person does something due to a wish from inside. Extrinsic motivation means that a person does something for the sake of its result. Amotivation means being unwilling to do something (Deci \& Ryan, 2000).

Gottfried (1985, 1990), found that academic intrinsic motivation in elementary and junior high school students had a positive correlation with student achievement and self-efficacy perception. Goldberg and Cornell (1998) conducted a study with a structural equation model and found that intrinsic motivation affected perceived competence, which accordingly affected academic achievement. The relevant literature also says that academic motivation has a positive influence on students' performance and achievement (Fortier, Vallerand \& Guay, 1995; Noels, Clement \& Pelletier, 2001; Wentzel \& Wigfield, 1998).

A review of the studies summarized above shows that the research is mainly focused on intrinsic motivation. Moreover, it was found that the studies which analyzed the influence of self-efficacy and metacognitive strategies on academic motivation were insufficient in general. It was observed that researchers mainly accepted motivational processes such as self-efficacy and goal orientation as academic motivation in the relevant literature. Since this study tackled the dimensions of academic motivation based on self-determination theory (intrinsic motivation, extrinsic motivation and amotiation), the author believes that the study will contribute to the literature. In addition, the relevant literature did not include any studies which were specifically based on academic motivation for learning biology since the studies were mainly about students' general academic motivation. This study will also contribute to the field of science education in this respect.

This study aimed to analyze the relationship between high school students' self-efficacy perceptions, the metacognitive strategy use and their academic motivation to learn biology. The structural model created for this purpose is shown in Figure 1.

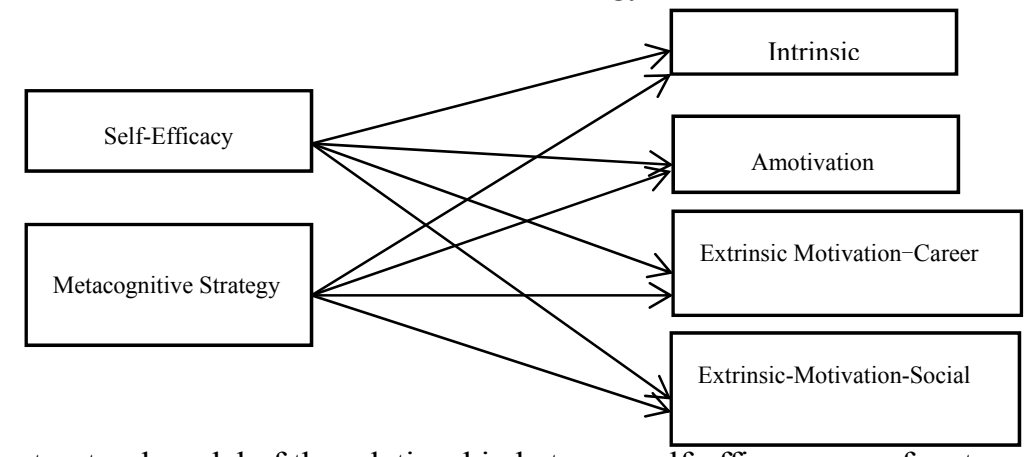

Figure 1. The structural model of the relationship between self-efficacy, use of metacognitive strategies and academic motivation 


\section{Method}

\subsection{Study Sample}

The sample of the study included 286 high school students. The author randomly selected three schools of the five Anatolian high schools in Kars, Turkey, and included 136 female and 150 male students in the sample. Anatolian high schools provide a four-year education which prepares students for higher education according to their interests, talents and achievement. At these schools, students can select specific courses according to the field they want to study at university. The author selected the participants of this study from classes that attend the biology course. The students' ages ranged between 15 and 17, and their GPA in biology was 3.13 on a scale of 5 .

\subsection{Data Collection Tools}

\section{Self-efficacy for Learning and Performance Scale}

To determine high school students' levels of self-efficacy for learning biology, the author used the Self-efficacy for Learning and Performance sub-scale of the Motivational Strategies for Learning Questionnaire (MSLQ). Sungur (2004) translated the scale into Turkish and did the validity and reliability analyses. It is a 7-point Likert-type scale that includes eight items. Table 1 shows sample items, descriptive statistics and reliability value (alpha).

\section{Metacognitive Self-regulation Scale}

The author used the Metacognitive Self-Regulation, a sub-scale of the Motivational Strategies for Learning Questionnaire (MSLQ) scale to measure high school students' levels of using metacognitive strategies when learning biology. Sungur (2004) translated the scale into Turkish and did the validity and reliability analyses. It is a 7-point Likert type scale that includes 12 items. Table 1 demonstrates the sample items, descriptive statistics and reliability value (alpha).

\section{Academic Motivation Scale for Learning Biology}

The author used the Academic Motivation Scale for Learning Biology to measure students' motivation to learn biology. The scale was created by Aydın, Yerdelen, Gürbüzoğlu, Yalmancı and Göksu (2014), who also did the validity and reliability analyses. It is a 6-point Likert type scale which includes 19 items and four sub-dimensions. These sub-dimensions are intrinsic motivation (IM-6 items), amotivation (A-5 items), extrinsic motivation-career (EM-C-4 items) and extrinsic motivation-social (EM-S-4 items). Table 1 shows sample items, descriptive statistics and reliability value (alpha).

Table 1. Sample scale items and descriptive statistics

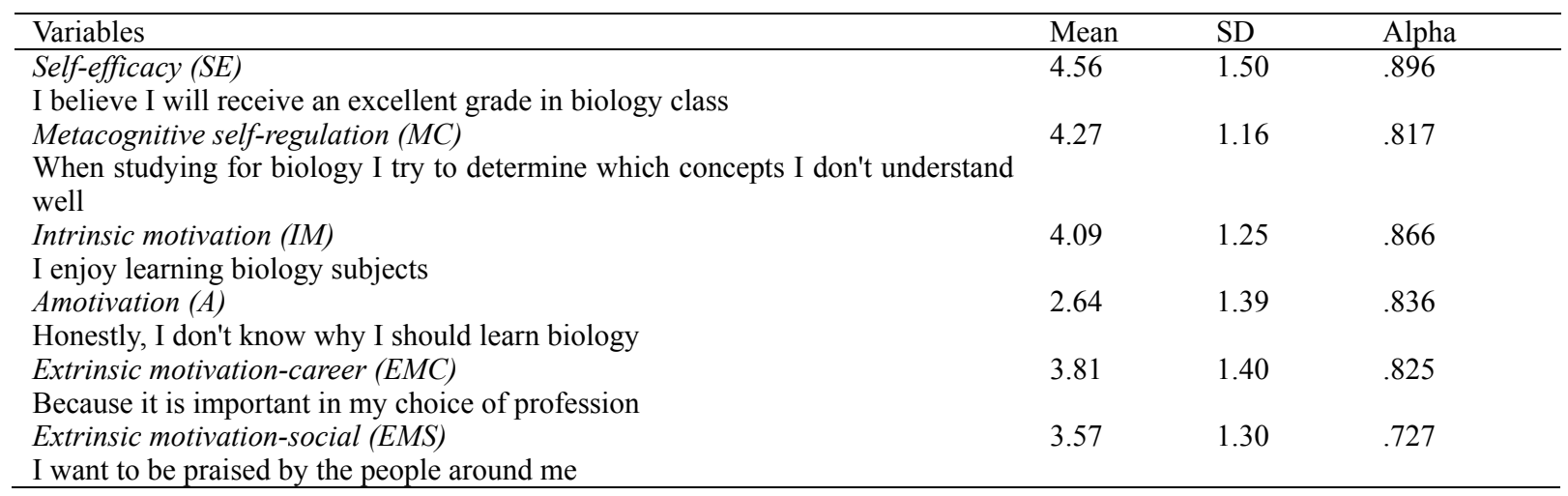

\subsection{Procedure}

Survey method was employed in the study. The author administered 'Self Efficacy for Learning and Performance' and 'Metacognitive Self-Regulation' subscales of Motivational Strategies for Learning Questionnaire (MSLQ) and Academic Motivation Scale for Learning Biology. The data were collected from the participants in their own classrooms, and those who voluntarily agreed to participate in the study after being informed about its purpose were included in the sample. Additionally, the students were informed that they could withdraw from the study whenever they wanted.

\section{Results}

\subsection{Correlations}

Table 2 shows the Pearson correlation coefficients generated by the correlation analysis conducted on the variables in the study. 
Table 2. Pearson correlation coefficients

\begin{tabular}{|c|c|c|c|c|c|c|}
\hline Variables & SE & $\mathrm{MC}$ & IM & A & EMC & EMS \\
\hline Self efficacy (SE) & 1 & $.588 * *$ & $.480 * *$ & $-.359 * *$ & $.366^{* *}$ & $.209 * *$ \\
\hline Metacognitive self-regulation (MC) & & 1 & $.402 * *$ & $-.258 * *$ & $.413 * *$ & $.307 * *$ \\
\hline İntrinsic motivation (IM) & & & 1 & $-.507 * *$ & $.475 * *$ & $.277 * *$ \\
\hline Amotivation (A) & & & & 1 & $-.327 * *$ & -.078 \\
\hline Extrinsic motivation-career (EMC) & & & & & 1 & $.366^{* *}$ \\
\hline Extrinsic motivation-social (EMS) & & & & & & 1 \\
\hline
\end{tabular}

Table 2 shows that self-efficacy and the use of metacognitive strategies were correlated with academic motivation, which was also implied by the structural model created for this study. The highest correlations were between self-efficacy and the use of metacognitive strategies $(\mathrm{r}=.588, \mathrm{p}<.01)$, and between self-efficacy and intrinsic motivation $(\mathrm{r}=.480, \mathrm{p}<.01)$. Moreover, there were positive correlations between intrinsic motivation and extrinsic motivation-career $(\mathrm{r}=.475, \mathrm{p}<.01)$, between the use of metacognitive strategies and extrinsic motivation-career $(\mathrm{r}=.413, \mathrm{p}<.01)$, and between the use of metacognitive strategies and intrinsic motivation $(\mathrm{r}=.402, \mathrm{p}<.01)$. In general, intrinsic motivation had a negative correlation with amotivation, and a positive correlation with other variables, which was the expected outcome.

In addition, it was found that amotivation had a negative correlation with self-efficacy, the use of metacognitive strategies, intrinsic motivation and extrinsic motivation-career.

\section{Path Analysis}

The path model (Figure 1) created with the purpose of determining the relationship between high school students' self-efficacy, levels of using metacognitive strategies in biology and motivation to learn biology was tested using LISREL 8.80 (Jöreskog and Sörbom, 2006). The results of the analysis showed that the fit indices had good consistency with the model's data set $\left(\chi_{(693)}^{2}=1400.28, p<.05 ; \chi^{2} / \mathrm{SD}=2.02\right.$; RMSEA $=0.060$; CFI $=.95$, NFI $=.91 ; \mathrm{NNFI}=.95$; $\mathrm{SRMR}=.078)$. Figure 2 shows the size and direction of the relationship between the variables in the path model.

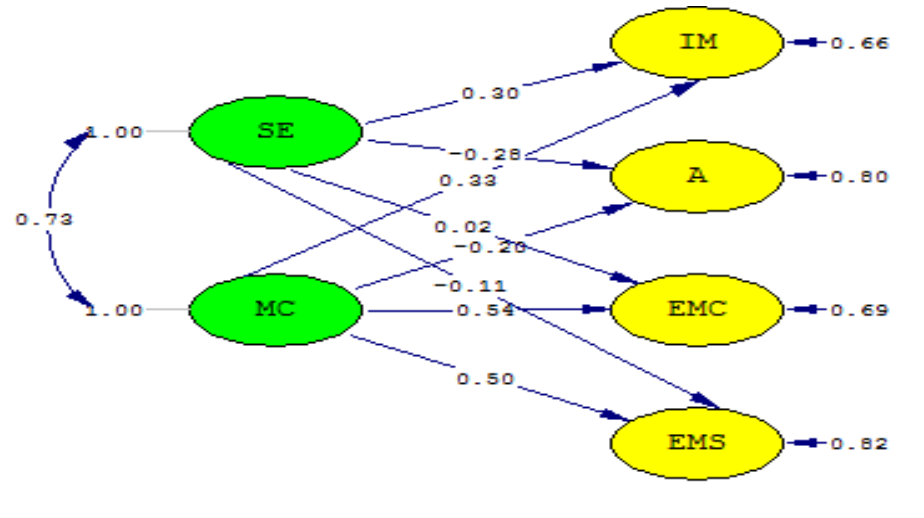

An analysis of the standardized path coefficients in this model showed that intrinsic motivation had positive relationship with self-efficacy $(\beta=.30)$ and the use of metacognitive strategies $(\beta=.33)$. The variables of self-efficacy and the use of metacognitive strategies explained $34 \%$ of the variance of intrinsic motivation. Amotivation variable was related only to self-efficacy $(\beta=-.28)$ and it was a negative relation. Self-efficacy explains $20 \%$ of the variance of amotivation. The extrinsic motivation-career $(\beta=-.54)$ and extrinsic motivation-social $(\beta=.50)$ variables related only to the use of metacognitive strategies. The use of metacognitive strategies explained $31 \%$ of extrinsic motivation-career variance and $18 \%$ of extrinsic motivation-social variance.

\section{Discussion}

This study aimed to determine the variables that affect high school students' motivation to learn biology. Moreover, the author tried to find the dimension of motivation by focusing on the sub-dimensions of motivation. Initially, the study analyzed the correlations between the variables. The results showed that self-efficacy had a strong correlation with the use of metacognitive strategies and intrinsic motivation. An analysis of the relevant studies indicated that they also found positive correlations between them (Coutinho, 2008; Coutinho \& Neuman, 2008; Kanfer \& Ackerman, 1989; Yerdelen, 2013; Walker et al., 2006). Coutinho (2008) found that there was a strong correlation between self-efficacy and metacognitive awareness, and that these variables affected student performance. This means that the students who have a high self-efficacy and metacognitive awareness have better performance. Additionally, Kanfer and Ackerman (1989) claim that it is more likely that people with strong self-efficacy will use metacognitive strategies. 
Another noteworthy result of the study was that amotivation had a negative correlation with self-efficacy, the use of metacognitive strategies, intrinsic motivation and extrinsic motivation-career. This is due to the fact that students who are unenthusiastic about and uninterested in biology have low self-efficacy and internal motivation, cannot use their metacognitive strategies at a sufficient level and do not think that learning biology will contribute to their selection of a future profession. Walker et al. (2006) and Turner, Chandler and Heffer (2009) suggested that amotivation and self-efficacy had a negative correlation. Vallerand et al. (1993) also says that amotivation has negative correlations with other variables of motivation.

This study conducted a path analysis on the relationship between self-efficacy, the use of metacognitive strategies and academic motivation. The results of this analysis indicated that self-efficacy and the use of metacognitive strategies predicted students' intrinsic motivation in a positive and significant way. A review of the relevant studies showed that the results were consistent with the relevant literature (Walker et al., 2006; McAuley, Wraith, Duncan, 1991; Lau \& Chan, 2003; Tas, Brown, Esen-Danaci, Lysaker \& Brüne, 2012; Vandergrift, 2005; Landine \& Stewart, 1998). In addition, Lau and Chan (2003) suggested that intrinsic motivation had a stronger relationship with student ability and strategy use compared to the other variables of motivation. Ryan and Deci (2000b) said that efficacy belief could increase intrinsic motivation.

Another result of the study was that self-efficacy made a negative prediction of amotivation while the use of metacognitive strategies did not predict it. People who do not perceive a consistency between their acts and the results lose their motivation. They have neither intrinsic nor extrinsic motivation, regard themselves as insufficient and their participation in academic activities may cease (Vallerand et al., 1992). For this reason, it was an expected outcome that poorly motivated students had low self-efficacy, did not use metacognitive strategies and were not enthusiastic about the biology course. Baker (2004) determined that amotivation caused a high level of stress perception and poor psychosocial adjustment. Moreover, Vallerand and Bissonnette (1992) found that amotivation had a negative effect on the maintenance of a specific behavior. They also said that amotivation seemed to be a strong indicator of negative outcomes, which means that future studies should focus on amotivation.

Another result of the study implied that self-efficacy did not predict extrinsic motivation, while the use of metacognitive strategies predicted extrinsic motivation. In contrast with intrinsic motivation which is related to the natural satisfaction of an act, extrinsic motivation is related to performance for the sake of acquiring a result (Ryan \& Deci, 2000b). For this reason, it is estimated that the use of metacognitive strategies predicts extrinsic motivation, which is in contrast with self-efficacy. A review of the relevant literature showed that there are also studies which did not find any relationship between self-efficacy and extrinsic motivation (Walker et al., 2006). Similarly, Baleghizadeh and Rahimi (2011) found that the use of metacognitive strategies had a positive correlation with intrinsic and extrinsic motivation, while it did not have any correlation with amotivation, which is consistent with the results of this study. This means that the students who use metacognitive strategies have intrinsic and extrinsic motivation. Extrinsic motivation causes students to choose goals that they cannot reach. On the other hand, the students who have intrinsic motivation have fewer unreachable goals since they believe that they can achieve if they try (Shannon, 2008). This shows the effect of self-efficacy on intrinsic motivation.

\section{References}

Aydın, S., Yerdelen, S., Gürbüzoğlu, Y. S., \& Göksu, V. (2014). Academic motivation scale for learning biology: a scale development study. Education and Science, 39(176), 425-435. http://dx.doi.org/10.15390/eb.2014.3678

Baker, S. R. (2004). Intrinsic, extrinsic, and amotivational orientations: Their role in university adjustment, stress, well-being, and subsequent academic performance. Current Psychology,23(3), 189-202. http://dx.doi.org/10.1007/s12144-004-1019-9

Baleghizadeh, S., \& Rahimi, A. H. (2011). The relationship among listening performance, metacognitive strategy use and motivation from a self-determination theory perspective. Theory and Practice in Language Studies, 1(1), 61-67. http://dx.doi.org/10.4304/tpls.1.1.61-67

Bandura, A. (1977). Self-efficacy: toward a unifying theory of behavior change. Psychological Review, 84, 191-215. http://dx.doi.org/10.1037/0033-295X.84.2.191

Bandura, A. (1993). Perceived Self-efficacay in cognitive development and functioning. Educational Psychologist, 28(2), 117-148. http://dx.doi.org/10.1207/s15326985ep2802_3

Bandura, A. (1994). Self-Efficacy. In V. S. Ramachaudran (Ed.), Encyclopedia Of Human Behavior (Vol. 4, Pp. 71-81). New York: Academic Press. http://dx.doi.org/10.1017/CBO9780511527692

Bandura, A. (1995). Exercise of personal and collective efficacy in changing societies. In A. Bandura (Ed.), Self-Efficacy in Changing Societies (pp. 1-45). New York: Cambridge University Pres. 
Bandura, A. (1997). Self efficacy: The exercise of control. New York: W. H. Freeman and Company.

Biggs, J. (1988). The role of metacognition in enhancing learning. Australian Journal of Education, 32(2), 127-138. http://dx.doi.org/10.1177/000494418803200201

Biggs, J. B. (1985). The role of metalearning in study processes. British Journal of Educational Psychology, 55, 185-212. http://dx.doi.org/10.1111/j.2044-8279.1985.tb02625.x

Coutinho, S. (2008). Self-efficacy, metacognition, and performance. North American Journal of Psychology, 10(1), 165.

Coutinho, S. A., \& Neuman, G. (2008). A model of metacognition, achievement goal orientation, learning style and self-efficacy. Learning Environments Research, 11(2), 131-151. http://dx.doi.org/10.1007/s10984-008-9042-7

Deci, E. L., \& Ryan, R. M. (1985). Intrinsic motivation and self-determination in human behavior. New York: Plenum Press. http://dx.doi.org/10.1007/978-1-4899-2271-7

Deci, E. L., \& Ryan, R. M. (2000). The "what" and "why" of goal pursuits: Human needs and the self-determination of behavior. Psychological Inquiry, 11(4), 227-268. http://dx.doi.org/10.1207/S15327965PLI1104_01

Flavell, J. (1979). Metacognition and cognitive monitoring: A new area of cognitive-devel-opmental inquiry. American Psychologist, 34, 906-911. http://dx.doi.org/10.1037/0003-066X.34.10.906

Fortier, M. S., Vallerand, R. J., \& Guay, F. (1995). Academic motivation and school performance: Toward a structural model. Contemporary Educational Psychology, 20, 257-274. http://dx.doi.org/10.1006/ceps.1995.1017

Goldberg, M. D., \& Cornell, D. G. (1998). The influence of intrinsic motivation and self-concept on academic achievement in second-and third-grade students.Journal for the Education of the Gifted, 21(2), 179-205.

Gottfried, A. E. (1985). Academic intrinsic motivation in elementary and junior high school students. Journal of educational psychology, 77(6), 631-645. http://dx.doi.org/10.1037/0022-0663.77.6.631

Gottfried, A. E. (1990). Academic intrinsic motivation in young elementary school children. Journal of Educational Psychology, 82(3), 525. http://dx.doi.org/10.1037/0022-0663.82.3.525

Jöreskog, K. G., \& Sörbom, D. (2006). LISREL 8.80 for Windows [Computer Software]. Lincolnwood, IL: Scientific Software International, Inc.

Kanfer, R., \& Ackerman, P. L. (1989). Motivation and cognitive abilities: An integrative/aptitude-treatment interaction approach to skill acquisition. Journal of applied psychology, 74(4), 657. http://dx.doi.org/10.1037/0021-9010.74.4.657

Landine, J., \& Stewart, J. (1998). Relationship between Metacognition, Motivation, Locus of Control, Self-Efficacy, and Academic Achievement.Canadian Journal of Counselling, 32(3), 200-12.

Lau, K. L., \& Chan, D. W. (2003). Reading strategy use and motivation among Chinese good and poor readers in Hong Kong. Journal of Research in Reading, 26(2), 177-190. http://dx.doi.org/10.1111/1467-9817.00195

Long, J. F., Monoi, S., Harper, B., Knoblauch, D., \& Murphy, P. K. (2007). Academic motivation and achievement among urban adolescents. Urban Education, 42(3), 196-222. http://dx.doi.org/10.1177/0042085907300447

McAuley, E., Wraith, S., \& Duncan, T. E. (1991). Self - Efficacy, Perceptions of Success, and Intrinsic Motivation for Exercise1. Journal of applied social $\quad$ psychology, 21(2), $139-155$. http://dx.doi.org/10.1111/j.1559-1816.1991.tb00493.x

Noels, K. A., Cle'ment, R., \& Pelletier, L. G. (2001). Intrinsic, extrinsic, and integrative orientations of French Canadian learners of English. Canadian Modern Language Review, 57, 424-440. http://dx.doi.org/10.3138/cmlr.57.3.424

Pajares, F. (1996). Self-efficacy beliefs in academic settings. Review of educational research, 66(4), 543-578. http://dx.doi.org/10.3102/00346543066004543

Pajares, F. (2002). Overview of Social Cognitive Theory and of Self-Efficacy. Web: http://www.emory.edu/EDUCATION/mfp/eff.html 10.09.2010'da alınmıştır.

Paris, S. G., \& Winograd, P. (1990). Promoting metacognition and motivation of exceptional children. Remedial and special Education, 11(6), 7-15. http://dx.doi.org/10.1177/074193259001100604

Pintrich, P. R., \& DeGroot, E., V. (1990). Motivational and self-regulated learning components of classroom academic performance. Journal of Educational Psychology, 82(1), 33-40. http://dx.doi.org/10.1037/0022-0663.82.1.33

Ryan, R. M., \& Deci, E. L. (2000a). Intrinsic and extrinsic motivations: Classic definitions and new directions. Contemporary Educational Psychology, 25, 54-67. http://dx.doi.org/10.1006/ceps.1999.1020 
Ryan, R. M., \& Deci, E. L. (2000b). Self-determination theory and the facilitation of intrinsic motivation, social development, and well-being. American psychologist, 55(1), 68. http://dx.doi.org/10.1037/0003-066X.55.1.68

Schraw, G., \& Moshman, D. (1995). Metacognitive theories. Educational Psychology Review, 7(4), 351-371. http://dx.doi.org/10.1007/BF02212307

Schunk, D. H. (1989). Self-efficacy and achievement behaviors. Educational Psychology Review, 1, 173-207. http://dx.doi.org/10.1007/BF01320134

Shannon, S. V. (2008). Using metacognitive strategies and learning styles to create self-directed learners. Institute for Learning Styles Journal, 1, 14-28.

Smith, P. A. (2001). Understanding self-regulated learning and its implications for accounting educators and researchers. Issues in Accounting Education, 16(4), 663-700. http://dx.doi.org/10.2308/iace.2001.16.4.663

Sungur, S. (2004). An implementation of problem based learning in high school biology courses. Unpublished doctoral dissertation, Middle East Technical University, Ankara Turkey.

Tas, C., Brown, E. C., Esen-Danaci, A., Lysaker, P. H., \& Brüne, M. (2012). Intrinsic motivation and metacognition as predictors of learning potential in patients with remitted schizophrenia. Journal of psychiatric research, 46(8), 1086-1092. http://dx.doi.org/10.1016/j.jpsychires.2012.04.027

Turner, E. A., Chandler, M., \& Heffer, R. W. (2009). The influence of parenting styles, achievement motivation, and self-efficacy on academic performance in college students. Journal of College Student Development, 50(3), 337-346. http://dx.doi.org/10.1353/csd.0.0073

Vallerand, R. J., \& Bissonnette, R. (1992). Intrinsic, extrinsic, and amotivational styles as predictors of behavior: A prospective study. Journal of personality, 60(3), 599-620. http://dx.doi.org/10.1111/j.1467-6494.1992.tb00922.x

Vallerand, R. J., Pelletier, L. G., Blais, M. R., Briere, N. M., Senecal, C., \& Vallieres, E. F. (1992). The academic motivation scale: A measure of intrinsic, extrinsic, and amotivation in education. Educational and psychological measurement, 52(4), 1003-1017. http://dx.doi.org/10.1177/0013164492052004025

Vallerand, R. J., Pelletier, L. G., Blais, M. R., Brière, N. M., Senecal, C., \& Vallieres, E. F. (1993). On the assessment of intrinsic, extrinsic, and amotivation in education: Evidence on the concurrent and construct validity of the Academic Motivation Scale.Educational and psychological measurement, 53(1), 159-172. http://dx.doi.org/10.1177/0013164493053001018

Vandergrift, L. (2005). Relationships among motivation orientations, metacognitive awareness and proficiency in L2 listening. Applied linguistics, 26(1), 70-89. http://dx.doi.org/10.1093/applin/amh039

Walker, C. O., Greene, B. A., \& Mansell, R. A. (2006). Identification with academics, intrinsic/extrinsic motivation, and self-efficacy as predictors of cognitive engagement. Learning and Individual Differences, 16(1), 1-12. http://dx.doi.org/10.1016/j.lindif.2005.06.004

Wentzel, K. R., \& Wigfield, A. (1998). Academic and social motivational influences on students' academic performance. Educational Psychology Review, 10(2), 155-175. http://dx.doi.org/10.1023/A:1022137619834

Yerdelen, S. (2013). Multilevel investigations of students' cognitive and affective learning outcomes and their relationships with perceived classroom learning environment and teacher effectiveness. Unpublished dissertation, Middle East Technical University, Ankara, Turkey.

Zimmerman, B. J. (1989). A social cognitive view of self-regulated academic learning. Journal of Educational Pyschology, 81(3), 329-339. http://dx.doi.org/10.1007/978-1-4612-3618-4

Zimmerman, B. J. (1990). Self-regulated learning and academic achievement: An overview. Educational Psychologist, 25(1), 3-17. http://dx.doi.org/10.1207/s15326985ep2501_2

Zimmerman, B. J. (2002). Becoming a self-regulated learner: An overview. Theory into Practice, 41(2), 64-70. http://dx.doi.org/10.1207/s15430421tip4102_2 